\title{
Firing temperature determination and thermoluminescence dating of a brick with cuneiform characters found in the ruins of Ancient Babylon
}

\author{
Rodrigo P. da Silva * \\ Diego R.G. Tudela * \\ Casimiro S. Munita *** \\ Roberto Hazenfratz *** \\ Sonia H. Tatumi \\ Marcio Yee \\ Juan C.R. Mittani
}

SILVA, R.P.; TUDELA, D.R.G.; MUNITA, C.S.; HAZENFRATZ, R.; TATUMI, S.H.; YEE, M.; MITTANI, J.C.R. Firing temperature determination and thermoluminescence dating of a brick with cuneiform characters found in the ruins of Ancient Babylon. R. Museu Arq. Etn., 28: 58-69, 2017.

Abstract: This paper aims to study a brick with inscriptions in cuneiform characters in which the sentences are almost complete. Typological studies in agreement with historical records suggest that the tablet was manufactured in the 6th century BCE during the dynasty of Nebuchadnezzar II, Great King of Babylon. The sample was studied by X-ray diffraction analysis (XRD), electron paramagnetic resonance (EPR), thermoluminescence (TL), and instrumental neutron activation analysis (INAA) techniques. The results showed that the brick is 2350 years old $( \pm 40)$ and its firing temperature was lower than $400^{\circ} \mathrm{C}$.

Keywords: XRD; EPR; TL; INAA; Babylonian cuneiform brick.

\section{Cover letter}

A lthough the need for interdisciplinary research appears to be contemporary, its importance is not new. Many researchers whose discoveries are the foundation of the

* Professor at Centro Universitário Adventista de São Paulo, Campus Engenheiro Coelho.

<rodrigo.silva@unasp.edu.br>

** Doctorate student at Universidade de São Paulo.

<diego_tudela@yahoo.com.br>

*** Researcher from Instituto de Pesquisas Energéticas e

Nucleares.<camunita@ipen.br> basic sciences were interdisciplinary in a Renaissance sense.

Today it is possible to see an increasingly movement of research towards more and more interdisciplinary endeavours. Effective collaboration between experts of different

\footnotetext{
**** PhD from Instituto de Pesquisas Energéticas e Nucleares. <hazenfratz@gmail.com>

***** Professor at Universidade Federal de São Paulo, Campus Baixada Santista. <sonia.tatumi@gmail.com> ***** Professor at Universidade Federal de São Paulo. <marcioyee@hotmail.com>

******* Professor at Universidade Federal de São Paulo. <juanmittani603@hotmail.com>
} 
disciplines is necessary to maximize the potential benefits of interdisciplinary for future research activity. This paper analyses an approach to the Middle East Archaeology, through the eyes of the experts on Thermoluminescence. Their skills are necessary for successful cross-disciplinary collaboration from the perspective of an interdisciplinary group of researchers.

When it comes to dating archaeological samples, several timescale problems arise. For example, the multiply forms of accounting the History: the Greeks consider the first Olympic Games as the beginning or 776 BC; Muslims the Prophet's departure from Mecca, or the Hegira, at AD 662. The Mayan calendar used 3114 BC and Christians the current BC and $\mathrm{AD}$. Beyond that, the relative chronology used by archaeologists (seriation, stratigraphy etc.) also presents several limitations.

For this reason, it is imperative to find a better method which can be a universal dating technique that can be applied anywhere in the world. The absolute dating can be a solution not just to reveal the real date of a sample but also to verify its authentication and its material history (its making, feedstock, conditions of manufacturing etc.).

The problem is that, despite of the advancing of the techniques towards maturity in few years of contribution and interdisciplinary dialogue, its use in Brazilian research has taking a very fairly place. Then, the application of this method on an artifact from the collection of a Museum in São Paulo, Brazil can be very interesting not just to confirm, correct or discovery elements from the sample as also to contribute for new horizons on future partnership between Physics, Archaeologists and other scientific areas.

\section{Introduction}

The Neo-Babylonian Empire, 626539/8 BCE, located in Southern-Central Mesopotamia, today Iraq, was an ancient Akkadian speaking Semitic State. According to sources, after a long hegemony of Assyrians, the Chaldeans regrouped, made a rebellion, defeated the Assyrian army and finally, gained the total control of Babylonian Plan. They established a powerful dynasty of Babylonian kings, named also XI Dynasty, Neo-Babylonian or Chaldean Dynasty.

The two most famous kings of this new age were Nabu-apla-usur or Nabopolassar, 626-605 BC, and his son Nabu-kudurri-usur or Nebuchadnezzar II, 606/5-562 BCE.

That dynasty was marked by several political and military conflicts. After of some years, this superpower established peaceful relations with other communities by means of a series of treaties, contributing to international commerce growth and communication between different cultures.

The cultural exchange is reflected in the Babylonian building style, attaching to a sophisticated design with great figures of bulls, lions and dragons crafted at the original walls of the city and main Temples and Palaces (Seymor 2014). At the beginning, the study and interpretation of many documents of that period was difficult because of the language, that had been translated by experts and assyriologists. Other challenge, still present in today's research, is the verification of date and authenticity of the many tablets with cuneiform inscriptions that are in the collections of several museums around the world (Zink \& Porto 2005).

Before the advent of modern methods of analysis from the fields of physics, chemistry or other sciences, answering questions of "why?", "how?", "where?" and "when?" in studies of the natural and man-made objects involved only classical methods of analysis. There is no doubt that if an artifact is held in hand, its age and authenticity is of utmost interest. The most classical dating methodology is based on seriating, stylistic technique, clay and pigment (Artioli 2010; Ashmore \& Sherer 2013). However, these approaches may reveal which objects belong together, but not their age in a quantitative manner. Zink \& Porto (2005) showed that several terracotta tablets from Thebes, Tanagra and Athens in the Museé du Louvre collections are modern pieces with age $150 \pm 50$ years. Goedicke (1994) found that approximately $20 \%$ of the 
Firing temperature determination and thermoluminescence dating of a brick with cuneiform characters found in the ruins of Ancient Babylon

R. Museu Arq. Etn., 28: 58-69, 2017.

Tanagra figurines in the Berlin collection are contemporary. Answers on material chronology can be partially obtained if an association is established between the object to be dated and another one of known age. By whatever means, except in few undoubted cases, such associations remain questionable to a certain extent.

For a long time, several techniques from physics and chemistry have been applied to archaeological studies to answer those questions related with the authentication of pieces of art or objects that are considered cultural heritage of a country (Goren, Mommsen \& Klinger 2011). Among the available options, thermoluminescence dating (TL) as an authenticity test method is well established and practically is the main technique applied for artifacts pyrotechnologically manufactured, such as ancient clay tablets (Bouquillon et al. 2003).
In this work, it is presented a study of one brick that, apparently, is from the neoBabylonian period. The sample was analyzed by XRD, EPR, TL, and INAA.

\section{Historical background of the sample}

In 2002, the Museu de Arqueologia Bíblica of Centro Universitário Adventista de São Paulo, Campus 2, São Paulo, Brazil, acquired one piece of terracotta brick, coming from the ruins of an ancient Babylon site, in Iraq, which was named $\mathrm{BAB}_{1}$ in this work. The artifact measures $27 \times 17 \times 8 \mathrm{~cm}$ with three cuneiform lines in almost complete sentences, and their decipherment and translation became a special project of the museum. The sample is depicted in Fig. 1.

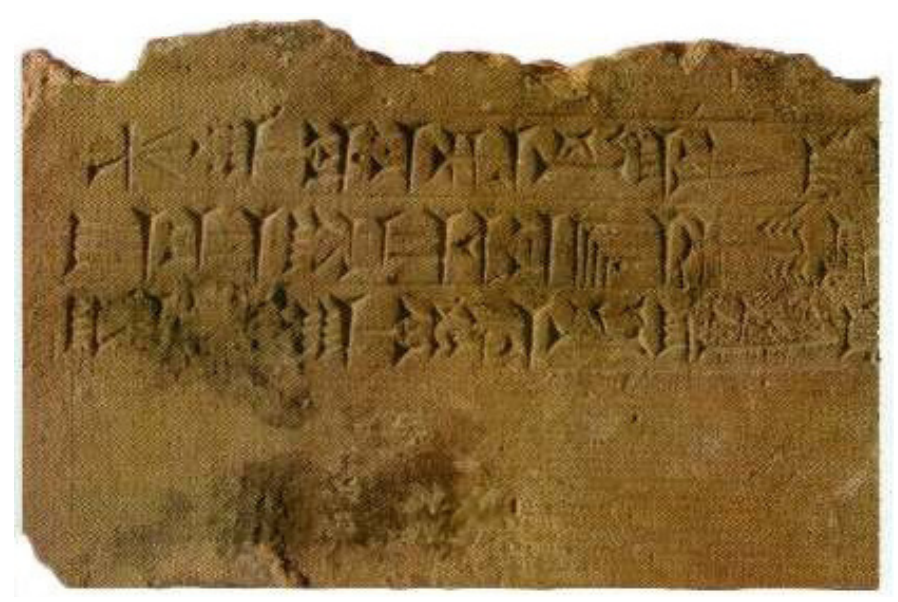

Fig. 1. Brick with cuneiform characters, supposed to be a kind of kingship inscription used during the Neo-Babylonian Empire period (626-539/8 BCE) - photography by Rodrigo Silva.

Source: Authors.

The transliteration adopted by the Museum is based on the Assyrisch-babyloniche Zeichenliste by Borger (1981), which varies only slightly from the Manuel d'Épigraphie akkadienne (Labat \& Malbran-Labat 1995). Before being presented to the public, that inscription, and its transliteration and translation, was personally verified and edited by several assyriologists (Everling 2000). The uppercase letters pertain to Sumerian, and the lowercase ones, to Akkadian.

The inscription consists of three parallel lines, read left to right, in neo-Babylonian style, used in the years 625 to $539 \mathrm{BC}$. It was a first paleographic indication of the artifact's age. The transliteration is 


\author{
d.NA3-ku-du2r-ri-URU3 LUGAL KA2. \\ DINGIR.RA.KI [za-nin] \\ E2.SAG.IL2 u3 E2.ZI.DA IBILA [[x]] \\ Sha d.NA3.IBILA.URU3 LUGAL KA2. \\ DINGIR.[RA.KI]
}

The last two symbols in the second line are erased, but it suggests an error made by the scribe. Since the brick is broken on the right side, the inscription's ending has been reconstructed based on the analysis of other inscriptions, with similar sentence structures. It is possible that the missing piece refers to IBILA A- [sha-re-du], meaning "exalted firstborn". Regarding the final transliteration, Na3.Ibila.URU3, there are no doubts that the name Nabu-apal-uszur is that of Nabopolazzar, the father of Nebuchadnezzar.

The assumed translation is:

$$
\begin{aligned}
& \text { (I am) Nebuchadnezzar, king of } \\
& \text { Babylon [provider] } \\
& \text { (of the temples) of Esagila and Ezida, } \\
& \text { first-born son } \\
& \text { of Nabopolazzar, king of Babylon } \\
& \text { (Silva, 2005) }
\end{aligned}
$$

Indeed, following the defeat of the Assyrian Empire between 614-609 BC, Nebuchadnezzar II, rebuilt the city of Babylon on a great scale. It has been estimated that 15 million baked bricks were used in the construction or expansion of the official buildings, specially the temples of Esagila and Ezida - mentioned in the inscription. The bricks were usually squared and often bear cuneiform inscription - generally made of stamp - as the sample showed here or occasionally written by hand.

The brick inscription is widely known kind of kingship seal, already found in Babylon and Borsipa. In ancient times, they were located on the walls of the main temples and palaces of the king. The content varies slightly in its context and some of them are displayed at the British Museum, in London (Mitchell 2004). The clay tablet was an ancient form of "royal signature", used by Nebuchadnezzar when erecting various monuments.

The reference to Esagila and Ezida is also important, as they are the names of the temple
Marduke (Bel), also known as Nebo or Nabû ("father of culture") in Borsipa. Esagila translates to house of the elevated tower or house that lifts one's head, and Ezida means the house of peace or House of Knowledge. All those terms are very suggestive titles that demonstrate the "pietistic" tone of Babylonian politics and religion.

Esagila stands out in relation to Ezida not only in terms of size, but also due to its dedication to Marduk, the main deity of the Babylonian pantheon. Cattle sacrifices were frequently offered there.

\section{Material and methods}

\section{Analytical techniques}

In this paper, it is presented a general description of the techniques used to study the sample. Details of each method are published in several papers and books (Artioli 2010; Cano et al. 2014; Cullity 1978; Glascock 1992; Glascock \& Neff 2003; Hazenfratz et al. 2016).

\section{X-ray diffraction, XRD}

X-ray diffraction uses X-rays beams of known wavelengths to determine the lattice spacing in crystalline structures for the identification of chemical compounds. It is the most widely applied method for structural identification of inorganic materials. Several authors provide a detailed description of the method (Cullity 1978; Jenkis 2002; Tite 1972;). The sensitivity of the technique depends on the mineral concerned. A well-crystallized mineral for which a particular reflection happens to be strong can be detected at the $1 \%$ level, whereas for a poorly crystallized mineral, concentrations in higher than $10 \%$ may be necessary.

\section{Electron paramagnetic resonance, EPR}

EPR spectroscopy was used to find the firing temperature of the sample (Bensimon, Deroide \& Zanchetta 1999; 
Firing temperature determination and thermoluminescence dating of a brick with cuneiform characters found in the ruins of Ancient Babylon

R. Museu Arq. Etn., 28: 58-69, 2017.

Bensimon et al. 1998; Mangueira et al. 2011). It is based on the absorption of microwave radiation by paramagnetic centers in the ionic crystal. The g-factor of some paramagnetic centers can vary with high annealing temperatures. Such is the case for the signal associated with $\mathrm{Fe}^{3+}$, contained in the sample.

\section{Thermoluminescence, TL}

Dating by TL technique is a particular application of ionizing dosimetry by crystal luminescence, in which there is a source of constant radiation (natural radioactivity). The first successful application of luminescence to archaeological material dating was extensively studied by a group at Oxford University, headed by Aitken (1985), but it took several more years and considerable research and development for this method to achieve the status of a reliable dating tool (Cano et al. 2015; Feathers 2003; Godfrey-Smith, Deal \& Kunelius, 1997; Lamothe 2004; Martini \& Sibilia 2001). The duration of irradiation is taken to be the same as the age of the sample, and this is proportional to the amount of the TL signal. Of course, it is essential to have an initial "zeroing of the luminescence signal", this generally being provided by the firing of the sample itself. The high temperature reached in the firing process of the object erases the previous luminescence signal by emptying all of the electronic traps.

In the TL dating, samples can be considered to consist of a number of crystalline inclusions embedded in the matrix, mainly quartz and feldspar. The inclusions act as dosimeters of the radiation arising mainly from the natural radioactivity of the sample. The natural radiation responsible for creating the conditions for luminescence has four primary sources: ${ }^{40} \mathrm{~K}$ and the decay chains of ${ }^{238} \mathrm{U},{ }^{235} \mathrm{U}$, ${ }^{232} \mathrm{Th}$ and cosmic radiation (Duttine et al. 2003; Rocca et al. 2012). In this study to evaluate the annual dose rate, $A D$, the $\mathrm{U}$, Th and $\mathrm{K}$ mass fractions were measured by means of INAA (Hazenfratz et al. 2016). The total regenerative dose method was used for the evaluation of equivalent dose, $D_{\mathrm{e}}$, (Godfrey-Smith et al. 1997; Martini \& Sibilia 2001), where the $D_{\mathrm{e}}$ was determined using TL growth curve. The age of the sample can be calculated by the equivalent dose divided by the annual dose rate. Water contents was assumed negligible, a sample depth of $10 \mathrm{~cm}$ was considered, and the cosmic rays contribution was theoretically determined using the geographic

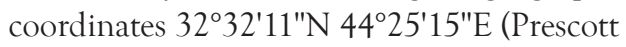
$\&$ Stephan 1982).

Instrumental neutron activation analysis, INAA

INAA can be used to determine mainly trace elements in many different matrices, as geological and archaeological materials. In this technique, the samples are submitted to a neutron flux in order to be activated. A typical thermal neutron source is a nuclear research reactor. Through the induced radioactivity, it is possible to determine the mass fractions of elements present in the sample by gamma spectrometry (Glascock \& Neff 2003).

\section{Sampling}

Initially, one small piece of approximately $2 \times 5 \mathrm{~cm}$ in the place with no cuneiform characters carefully removed from the brick. This procedure avoided the loss of historic information for the archaeologists and historians. The choice of the location of the sample was chosen in agreement with the curators.

For INAA, the side surfaces of the samples were cleaned and drilled to a depth of $2.3 \mathrm{~mm}$ using a tungsten carbide rotary file, attached to the end of a flexible shaft with variable speed drill. Then, powdered material was obtained by drilling about 5 holes through the wall. The powdered sample was dried in an oven at $105^{\circ} \mathrm{C}$ for $24 \mathrm{~h}$ and stored in a desiccator. About $100 \mathrm{mg}$ of the sample and the reference materials NIST-SRM 1633b, used as standard, and IAEA - Soil 7, used for analytical quality assessment were weighed into polyethylene 
involucres and wrapped in aluminum foils. The samples and the standards were irradiated at IEA-R1 research reactor, IPEN-CNEN/SP, to determine U, Th and $\mathrm{K}$ (Hazenfratz et al. 2016).

For TL, the same fragment was crushed in an agate mortar and sieved to retain grains with diameters between 0.080 and $0.180 \mathrm{~mm}$. The powdered material was submitted to chemical treatment in solutions of $\mathrm{H}_{2} \mathrm{O}_{2}, \mathrm{HCl}$ and $\mathrm{HF}$. The chemical treatment had three purposes: 1 ) to eliminate, although partially, organic matter and mineral carbonates, 2) partially corrode the surface of quartz grains, in such a way that the effect of $\alpha$-particles can be neglected (Aitken 1985) and 3) to eliminate fluorides which can be formed with HF etching. Magnetic minerals were separated with a magnet. After this process IRSL was applied to check the presence of feldspar, and no significant signal was observed. Grains with diameter smaller than $0.088 \mathrm{~mm}$ (170 mesh) were used for XRD and EPR measurements.

\section{Equipments}

The XRD measurements were performed with a RIGAKU model Miniflex II diffractometer working with $\mathrm{Cu}-\mathrm{K}$ radiation ( $\square=1.5418 \AA \AA$ ) $)$ and graphite monochromator in the diffracted beam, at $1.2 \mathrm{~kW}(30 \mathrm{kV}$, $15 \mu \mathrm{A})$. Spectra were taken in the range $5-80^{\circ} 2 \square$, at $2 \min ^{-1}$ (step size $=0.05^{\circ} 2 \square$; time $=1 \mathrm{~s})$. The evaluation of crystalline phases was carried out by comparison with standard crystallographic patterns.

For the EPR measurements, it was used a Bruker EMX EPR spectrometer operating at X-band frequency with $100 \mathrm{kHz}$ modulation frequency. One hundred milligrams of powdered sample were used for each measurement. Diphenil picryl hydrazyl (DPPH) was used for the calibration of the $g$ values of the defect centers.

The TL measurements of the quartz samples were performed using a Ris $\varnothing$ TL/OSL reader with a ${ }^{90} \mathrm{Sr} /{ }^{90} \mathrm{Y} \square$-particle source. Optical filters were Schott BG-39 and BG-3 and heating rate was $10^{\circ} \mathrm{C}$.
For INAA the sample was irradiated at the swimming pool research reactor IEA-R1 of the Nuclear and Energy Research Institute, IPEN-CNEN/SP, at a thermal neutron flux of $1.2 \times 10^{12} \mathrm{~cm}^{-2} \times \mathrm{s}^{-1}$ for $8 \mathrm{~h}$. Two measurement series were carried out, the radioisotopes ${ }^{42} \mathrm{~K}$ and ${ }^{239} \mathrm{~Np}$ to determine $\mathrm{K}$ and $\mathrm{U}$, respectively, were measured after 7 days of decay. The radioisotope ${ }^{233} \mathrm{~Pa}$ was measured to determine Th after 25-30 days of decay (Hazenfratz et al., 2016). The gamma spectrometry was carried out using a HPGe hyperpure detector, model GX 1925, from CANBERRA with resolution of $1.9 \mathrm{keV}$ at the $1332.05 \mathrm{keV}$ gamma peak of ${ }^{60} \mathrm{Co}$. The spectra were collected by a CANBERRA S-100 MCA with 8192 channels. The software Genie-2000 for NAA Processing Procedure, developed by Canberra, was used to analyze the gamma-ray spectra.

\section{Results and discussion}

The first study was carried out by means of XRD analysis with the purpose to study the mineralogical composition of the brick sample. For this technique, two aliquots with $100 \mathrm{mg}$ of powdered material were used. Fig. 2 shows the diffractogram obtained at room temperature in order to illustrate the main mineralogical variation.

The presence of quartz, calcite, fluorite, pentlandite and ralstonite are the principal chemical species found in the brick. In the sample there are two crystalline phases, pentlandite, $\mathrm{Fe}_{4.5}^{+2} \mathrm{Ni}_{4.5} \mathrm{~S}_{8}$, and ralstonite, $\mathrm{Na}_{0.5}(\mathrm{Al}, \mathrm{Mg})_{2}(\mathrm{~F}, \mathrm{OH})_{6} \times \mathrm{H}_{2} \mathrm{O}$, and are present with relatively high values.

The presence or absence of specific minerals can help in the identification of an approximate firing temperature range and the firing atmosphere. Often, the microstructural evolution during firing is also dependent on the type of clay, depending on the composition and impurities (McConville \& Lee, 2005, Papachristodoulou et al. 2006). Nevertheless, some general trends can be established. 
Firing temperature determination and thermoluminescence dating of a brick with cuneiform characters found in the ruins of Ancient Babylon

R. Museu Arq. Etn., 28: 58-69, 2017.

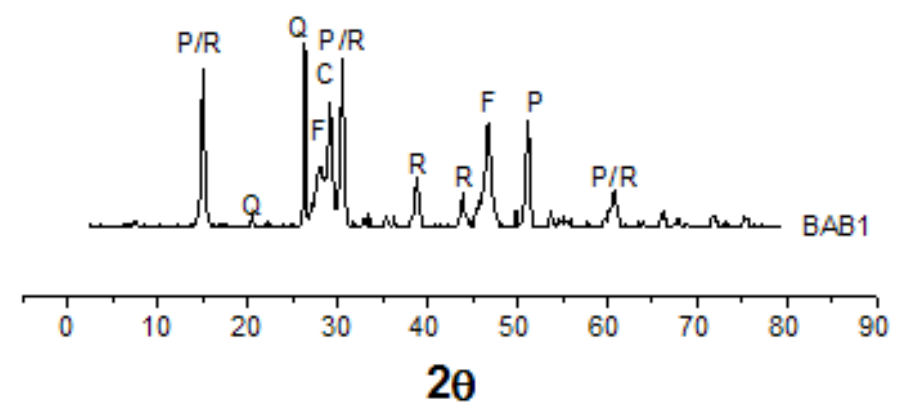

Fig. 2. Diffractogram X-ray diffraction of the brick. Peaks corresponding to each crystalline phase, where: $\mathrm{Q}=$ quartz, $\mathrm{C}=$ calcite, $\mathrm{F}=$ fluorite, $\mathrm{P}=$ pentlandite, and $\mathrm{R}=$ ralstonite.

Source: Authors.

Calcite, is a kind of calcium carbonate that is present in limestone and shells. If it occurs naturally in clays, the clay is described as calcareous. The presence of calcite in the spectrum indicates that the firing temperature is lower than $850^{\circ} \mathrm{C}$, which is the approximate maximum temperature at which calcite may still exist. When it decomposes, the calcium carbonate forms lime $(\mathrm{CaO})$, and carbon dioxide, according the following reaction (Rice 1987):

$$
\mathrm{CaCO}_{3} \rightarrow \mathrm{CaO}+\mathrm{CO}_{2} \uparrow
$$

Above $850^{\circ} \mathrm{C}$, the decomposition of calcite can give rise to high-temperature calcosilicates and alumino-calcosilicates, member of the pyroxene group, such as the diopside, plagioclase feldspars (anorthite), gehlenite and wollastonite (Papachristodoulou et al. 2006). Moorey (1994) carried out a mineralogical characterization of some clay sources from Iraq. In the light fraction, he found quartz, chert, opal chlorite, muscovite and calcite. In the heavy fraction, he found mainly iron ores, epidotes, amphiboles and pyroxenes.

In order to verify the firing temperature, the brick was analyzed by EPR. Aliquots of this sample were submitted to successive thermal treatment at high temperatures, where the $g$-value of $\mathrm{Fe}^{3+}$ changes (Bensimon et al. 1998). Thermal treatment was performed in a preheated oven in the temperature range from $400^{\circ} \mathrm{C}$ up to $1200^{\circ} \mathrm{C}$. Each aliquot was thermally treated for $30 \mathrm{~min}$. Each measurement was carried out with $50 \mathrm{mg}$ of the sample placed inside a quartz tube of $4 \mathrm{~mm}$ diameter.

Fig. 3A shows the EPR spectrum of the sample. It was observed a broad absorption around $g=2.0$. This line is characteristic of $\mathrm{Fe}^{3+}$ ion in an octahedral site. Furthermore, these ions are associated with hydrated species of $\mathrm{Fe}^{3+}$, which can be oxidized to $\mathrm{Fe}_{\mathrm{x}} \mathrm{O}_{\mathrm{y}}$ or $\mathrm{FeOOH}$ (Bensimon et al. 2000). The EPR spectrum also shows another line in the region of $g=4.3$, typical of $\mathrm{Fe}^{3+}$ in an orthorhombic site (Bensimon, Deroide \& Zanchetta 1999; Presciutti et al. 2005; Tani et al. 1997).

Fig. 3B shows the behavior of the $g$ factor as a function of the temperature for the sample. The $g$ value practically unchanged in the region of $400-1200^{\circ} \mathrm{C}$, indicating that was not burned in this temperature range. This result may confirm the possibility that the brick from neo-Babylonian period was not burned, and agreed with the XRD results, that showed the firing temperature, if it happened, was below $850^{\circ} \mathrm{C}$. It is more difficult to trace the origin of unfired or sun-baked clay products because they leave scarce and poorly recognizable archaeological records.

In accordance with the literature, several authors analyzed bricks with cuneiform characters and found that many were dried in the sun or air, remaining fragile. The brick studied in this work is very fragile, 
and was probably used to construct a temple wall, with cuneiform characters in honor of Nebuchadnezzar, as a prestige symbol. The raw materials for the brick production probably involved the use of lime and/or gypsum mixed with water to create a clay paste that harden upon drying.

Finally, TL measurements were also performed on the sample to calculate the equivalent dose, De. In this way, the total regenerative dose method with multiple aliquots and natural normalization was used (Murray \& Wintle 2000).

Fig. 4A shows the TL glow curve for the natural and irradiated samples, which were preheated at $150^{\circ} \mathrm{C}$ before the measurements in order to eliminate TL emission from shallow traps. TL characterization was carried out to study the thermal stability of this emission. It was observed a predominant peak at about $331^{\circ} \mathrm{C}$, when the TL glow was deconvoluted using computerized curve deconvolution analysis, CCDA Fig. 4B), (Afouxenidis et al. 2012). This peak is probably related to $325^{\circ} \mathrm{C}$ TL peak always found in quartz. The other peaks might be satellites, especially with high temperatures, which include the $375^{\circ} \mathrm{C}$ TL peak of quartz, which in the sample presented low intensity and large noise. Table 1 shows the TL traps parameters determined for each peak using CCDA. The other peak at $331^{\circ} \mathrm{C}$ has activation energy of $1.45 \mathrm{eV}$, the frequency factors $\mathrm{s}=5.249 \times 10^{10} \mathrm{~s}^{-1}$ and order kinetics was 1.2 , therefore this peak has mean life about $2 \times 10^{6} \mathrm{y}$, considering the environmental temperature about $298 \mathrm{~K}$, that is thermal stable enough to be used in TL dating.
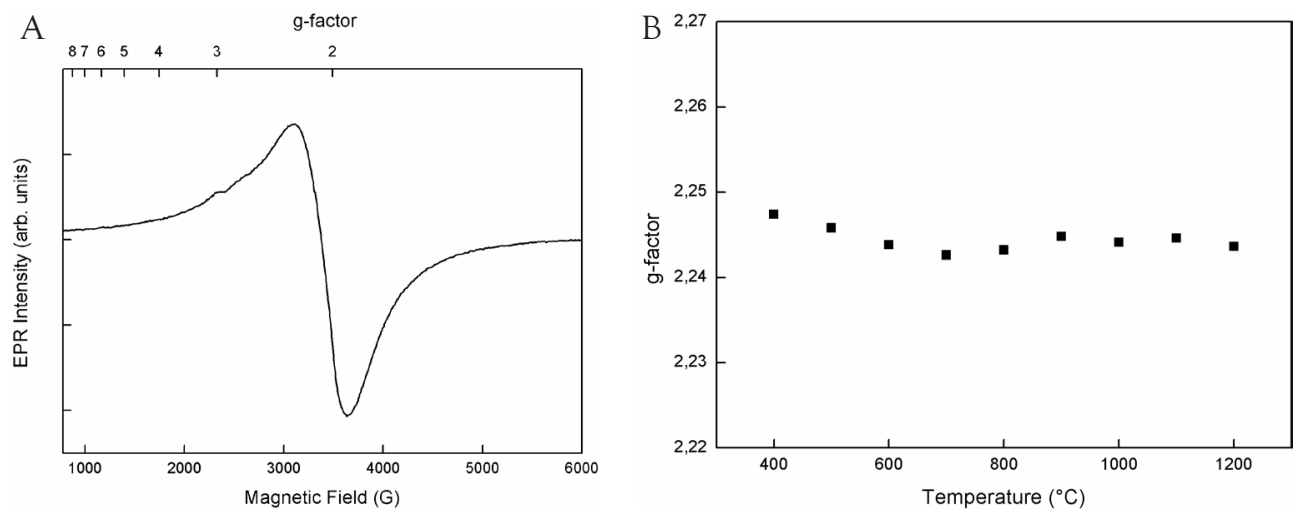

Fig. 3. Behavior of $g$-factor of $\mathrm{Fe}^{3+}$ at $g=2.0$ with heating temperature of the sample. Source: Authors.
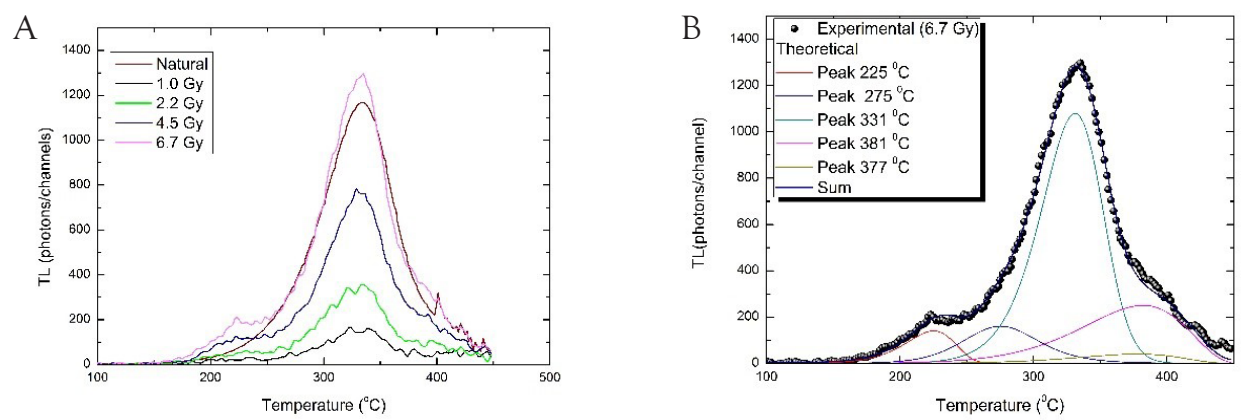

Fig. 4. a) Experimental TL glow curves for the natural and beta irradiated sample. b) Regenerated TL glow curve irradiated with 6.7 Gy and theoretical curves obtained by deconvolution using CCDA, FOM = 4.9\%. Source: Authors. 
Firing temperature determination and thermoluminescence dating of a brick with cuneiform characters found in the ruins of Ancient Babylon

R. Museu Arq. Etn., 28: 58-69, 2017.

\begin{tabular}{lccccc}
\hline & Peak 1 & Peak 2 & Peak 3 & Peak 4 & Peak 5 \\
\hline $\mathrm{I}_{\max }$ & 0.14 & 0.16 & 1.08 & 0.04 & 0.25 \\
$\mathrm{~T}_{\max }(\mathrm{K})$ & 225 & 275 & 331 & 377 & 381 \\
$\mathrm{E}(\mathrm{eV})$ & 1.11 & 1.20 & 1.45 & 0.80 & 0.80 \\
$\mathrm{~B}$ & 1.0001 & 1.8 & 1.2 & 0.8 & 0.8 \\
$\mathrm{~s}\left(\mathrm{~s}^{-1}\right)$ & $2.2440 \mathrm{E}+09$ & $1.0180 \mathrm{E}+11$ & $5.2490 \mathrm{E}+10$ & $3.2666 \mathrm{E}+05$ & $6.0085 \mathrm{E}+11$ \\
\hline
\end{tabular}

$\mathrm{I}_{\max }=$ maximum $\mathrm{TL}$ intensity $\mathrm{T}_{\max }=\mathrm{TL}$ peak temperature $\mathrm{E}=$ activation energy

$\mathrm{b}=$ kinetic order $\mathrm{s}=$ frequency fator

Table 1. TL traps parameters evaluated for quartz extracted from the brick tablet after deconvolution process with CCDA. $\mathrm{I}_{\max }=$ maximum TL intensity, $\mathrm{T}_{\max }=\mathrm{TL}$ peak temperature, $\mathrm{E}=$ activation energy, $\mathrm{b}=$ kinetic order, $\mathrm{s}=$ frequency fator.

Source: Authors.

Appling the multiple aliquots total regeneration protocol with natural normalization, we could have obtained a good $D_{\text {e }}$ plateau, shown in Fig. 5. The mean value of the $D_{\mathrm{e}}$ values calculated from 302 to $335^{\circ} \mathrm{C}$ was used to age determination, and it was estimated as $D_{e}=(6.13 \pm 0.06)$ Gy.

The annual dose (AD) rate was obtained using the $\mathrm{U}$, Th and $\mathrm{K}$ mass fraction obtained by INAA. The analysis of the same elements in the reference material IAEA Soil 7 showed that the accuracy and precision for $\mathrm{U}, \mathrm{Th}$ and $\mathrm{K}$ determination was less than $6 \%$ and it is in agreement with the criteria recommended by several authors (Bishop et al. 1990). Table 2 shows the $\mathrm{U}, \mathrm{Th}$ and $\mathrm{K}$ mass fraction, the annual and the equivalent dose values and the age.

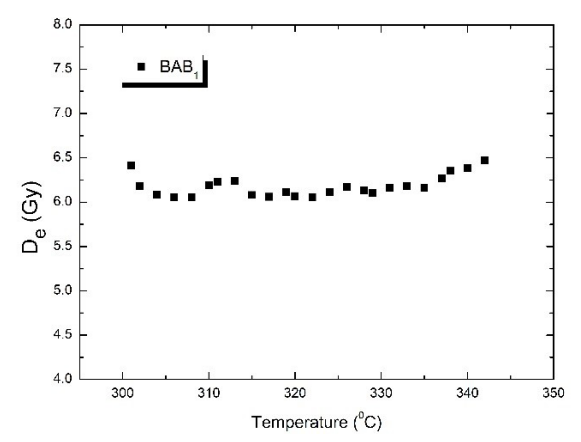

Fig. 5. Plateau test of equivalent dose versus TL intensity temperature for quartz extracted from the tablet. Source: Authors.

\begin{tabular}{ccccccc}
\hline Sample & $\mathrm{U}, \boldsymbol{\mu g} / \mathrm{g}$ & $\mathrm{Th}, \boldsymbol{\mu g} / \mathrm{g}$ & $\mathrm{K}, \%$ & $\mathrm{AD}, \mathrm{mGy} / \mathrm{y}$ & $D_{\mathrm{e}^{\prime}} \mathrm{Gy}$ & Age, years \\
\hline $\mathrm{BAB}_{1}$ & $2.3 \pm 0.1$ & $6.1 \pm 0.4$ & $1.4 \pm 0.1$ & $(2.6 \pm 0.3) 10^{-3}$ & $6.13 \pm 0.06$ & $2350 \pm 40$ \\
\hline
\end{tabular}

Table 2. $\mathrm{U}$, Th and $\mathrm{K}$ mass fraction, annual dose, equivalent dose and age of the tablet. Source: Authors.

By that procedure, using the equivalent dose, $D_{\mathrm{e}}$, and the annual dose rate, $A D$, the tablet was 2350 years old $( \pm 40)$, which differ very little from the 2600 years for the expected age for the archaeological piece. However, this age was determined without water content correction. The water in the soil has an attenuating effect on the environmental radiation. Therefore, samples dated without attention of their water content will supply ages younger than the real ones. Unfortunately, it is difficult to assess the amount of water that this sample would have absorbed over their existence. However, as an indication of its influence, if the amount of water was estimated in $10 \%$, the age of the brick would be around $2690 \pm$ 110 years. 


\section{Conclusion}

A brick with cuneiform characters, supposedly from the Neo-Babylonian Empire period (626-539/8 BCE), was studied by XRD, INAA, EPR, and TL with the purpose to assess if the sample is of archaeological or contemporary origin. The XRD results showed that the main mineralogical species found in the brick are quartz, calcite, fluorite, pentlandite, and ralstonite. The EPR analysis showed that it was burned at temperatures lower than $400^{\circ} \mathrm{C}$. Regarding the firing temperature, the sample was probably unfired and used to construct a temple wall, in honor of Nebuchadnezzar, as a prestige symbol. The
TL studies showed that the age of the sample is estimated in $2350 \pm 40$ years, close to the expected age regarding the Neo-Babylonian Empire. Furthermore, our study showed that the age estimated for the brick tablet is in agreement with the ages of Tanagra terracottas samples in the Louvre collections, around $2300 \pm 400$ years (Zink \& Porto 2005). In fact, the brick might be part of the material vestiges of a period referred to in the Babylonian Ruin of Esagila Chronicle (BCHP 6 - one of the historiographical texts from ancient Babylonia at the time of Seleucid Monarchy around $268 \mathrm{BCE})$, as an attempt to rebuild the temples of the city that was, according to line $10^{\prime}$ IZI ŠUB = miqitti išâti, literally "fall of fire".

SILVA, R.P.; TUDELA, D.R.G.; MUNITA, C.S.; HAZENFRATZ, R.; TATUMI, S. H.; YEE, M.; MITTANI, J.C.R. Determinação da temperatura de queima e datação por termoluminescência de um tijolo com caracteres cuneiformes encontrado nas ruínas da antiga Babilônia. R. Museu Arq. Etn., 28: 58-69, 2017.

Resumo: Este artigo tem por objetivo estudar um tijolo com inscrições em caracteres cuneiformes cujas sentenças estão praticamente completas. Estudos tipológicos correspondentes aos relatos históricos sugerem que o tijolo foi manufaturado no século VI a.C., durante a dinastia de Nabucodonosor II, grande monarca da Babilônia. A amostra foi estudada através da difração de raios-X (DRX), ressonância paramagnética de elétron (RPE), termoluminescência (TL) e técnicas de análise por ativação instrumental com nêutrons (AAIN). Os resultados demonstraram que o tijolo tem 2350 anos de idade $( \pm 40)$ e queima menor que $400^{\circ} \mathrm{C}$.

Palavras-chave: Difração de raios-X; Ressonância paramagnética de elétron; Termoluminescência; Análise por ativação instrumental com nêutrons; Tijolo babilônico com escrita cuneiforme.

\section{Bibliographic references}

Afouxenidis, D. et al. 2012. Computerised curve deconvolution of TL/OSL curves using a popular spreadsheet program. Radiation Protection Dosimetry 149 (4): 363-370.

Aitken, M.J. 1985. Thermoluminescence dating. Academic, London.
Artioli, G. 2010. Scientific methods and cultural heritage: an introduction to the application of materials science to archaeometry and conservation science. Oxford University, Oxford.

Ashmore, W.; Sherer, R. 2013. Discovering our past: $a$ brief introduction to archaeology. 6. ed. McGrawHill, Columbus. 
Firing temperature determination and thermoluminescence dating of a brick with cuneiform characters found in the ruins of Ancient Babylon

R. Museu Arq. Etn., 28: 58-69, 2017.

Bensimon, Y. et al. 1998. Electron spin resonance and dilatometric studies of ancient ceramics applied to the determination of firing temperature. Japanese Journal of Applied Physics 37 (8): 4367-4372.

Bensimon, Y. et al. 2000. Nature and thermal stability of paramagnetic defects in natural clay: a study by electron spin resonance. Journal of Physics and Chemistry of Solids 61 (10): 1623-1632.

Bensimon, Y.; Deroide, B.; Zanchetta, J.V. 1999. Comparison between the electron paramagnetic resonance spectra obtained in X-and W-bands on a fired clay: a preliminary study. Journal of Physics and Chemistry of Solids 60 (6): 813-818.

Bishop, R.L. et al. 1990. Sensitivity, precision and accuracy: their roles in ceramic compositional data bases. American Antiquity 55 (3): 537-546.

Borger, R. 1981. Assyrisch-babylonische Zeichenliste. Neukirchener Verlag, Neukirchen-Vluyn.

Bouquillon, A. et al. 2003. Authenticité, matières et couleurs: etude en laboratoire des Tanagréennes du Louvre. In: Jeammet, V. (Ed.). Tanagra: mythe et archéologie. Réunion des Museés Nationaux, Paris, 298-301.

Cano, N.F. et al. 2014. OSL and EPR dating of pottery from the archaeological sites in Amazon Valley, Brazil. Quaternary International 352: 176-180.

Cano, N.F. et al. 2015. Dating and determination of firing temperature of ancient potteries from São Paulo II archaeological site, Brazil by TL and EPR techniques. Journal of Cultural Heritage 16 (3): 361-364.

Cullity, B.D. 1978. Elements of X-ray diffraction. 2. ed. Addison-Wesley, Reading.

Duttine, M. et al. 2003. Electron spin resonance of $\mathrm{Fe}^{3+}$ ion in obsidians from Mediterranean islands. Application to provenance studies. Journal of Non-Crystalline Solids 323 (1-3): 193-199.
Everling, J. 2000. The neo-Babylonian royal inscription of the Bibliothèque Nationale et Universitaire de Strasbourg. Nouvelles Assyriologiques Brèves et Utilitaires 14 (3): 62.

Feathers, J.K. 2003. Use of luminescence dating in archaeology. Measurement Science and Technology 14 (9): 1493-1509.

Glascock, M.D. 1992. Characterization of archaeological ceramics at MURR by neutron activation analysis and multivariate statistics. In: Neff, H. (Ed.). Chemical characterization of ceramic pastes in archaeology. Prehistory, New York, 11-26.

Glascock, M.D.; Neff, H. 2003. Neutron activation analysis and provenance research in archaeology. Measurement Science and Technology 14 (9): 1516-1526.

Godfrey-Smith, D.I.; Deal, M.; Kunelius, I. 1997. Thermoluminescence dating of St. Croix ceramics: chronology building in Southwestern Nova Scotia. Geoarchaeology 12 (3): 251-273.

Goedicke, C. 1994. Authenticity of Tanagra figurines based on thermoluminescence method. In: Kriseleit, I.; Zimmer, G.; Cordelia, J. (Eds.). Middle-class worlds, hellenistic terracotta and recreation in $19^{\text {th }}$ Century. Philipp von Zabern, Mainz am Rhein, 77-81.

Goren, Y.; Mommsen, H.; Klinger, J. 2011. Nondestructive provenance study of cuneiform tablets using portable X-ray fluorescence (pXRF). Journal of Archaeological Science 38 (3): 684-696.

Hazenfratz, R. et al. 2016. Study of exchange networks between two Amazon archaeological sites by INAA. Journal of Radioanalytical and Nuclear Chemistry 309: 195-205.

Jenkis, R. 2002. X-ray powder methods. In: McGrawHill Education. Encyclopedia of Science and Technology. 9. ed. McGraw Hill Education, New York, 668-673. 
Labat, R.; Malbran-Labat, F. 1995. Manuel dépigraphie akkadienne: signes, syllabaire, idéogrammes. Paul Geuthner, Paris.

Lamothe, M. 2004. Optical dating of pottery, burnt stones, and sediments from selected Quebec archaeological sites. Canadian Journal of Earth Sciences 41 (6): 659-667.

Mangueira, G.M. et al. 2011. A study of the firing temperature of archeological pottery by X-ray diffraction and electron paramagnetic resonance. Journal of Physics and Chemistry of Solids 72 (2): 90-96.

Martini M.; Sibilia, E. 2001. Radiation in archaeometry: archaeological dating. Radiation Physics and Chemistry 61 (3-6): 241-246.

McConville, C.J.; Lee, W. 2005. Microstrutural development on firing illite and smectite clays compared with that in kaolinite. Journal of the American Ceramic Society 88 (8): 2267-2276.

Mitchell, T.C. 2004. The Bible in the British Museum: interpreting the evidence. Paulist, Mahwah.

Moorey, P.R.S. 1994. Ancient Mesopotamian materials and industries: the archaeological evidence. Clarendon, Oxford.

Murray, A.S.; Wintle, A. G. 2000. Application of the single-aliquot regenerative-dose protocol to the $375{ }^{\circ} \mathrm{C}$ quartz TL signal. Radiation Measurements 32 (5-6): 579-583.

Papachristodoulou, C. et al. 2006. A study of ancient pottery by means of X-ray fluorescence spectroscopy, multivariate statistics and mineralogical analysis. Analytica Chimica Acta 573-574: 347-353.
Presciutti, F. et al. 2005. Electron paramagnetic resonance, scanning electron microscopy with energy dispersion X-ray spectrometry, X-ray powder diffraction, and NMR characterization of iron-rich fired clays. The Journal of Physical Chemistry B 109 (47): 22147-22158.

Prescott, J.R.; Stephan, L.G. 1982. The contribution of cosmic radiation to the environmental dose for thermoluminescence dating: latitude, altitude and deph dependences. PACT (Council of Europe) 6: 17-25.

Rice, P.M. 1987. Pottery analysis: a sourcebook. The University of Chicago, Chicago.

Rocca, R.R. et al. 2012. OSL dating of coastal post-barreira sediments from Northern Brazil. Journal of Earth Science and Engineering 2 (9): 515-521.

Seymour, M. 2014. Babylonian art and architecture. Art History, Jan-2014. Available at: <https:// goo.gl/tS9aak>. Access on: 9/1/2018. doi: 10.1093/OBO/9780199920105-0038.

Silva, R.S. 2005. A historicidade de Nabudodonosor: análise paleográfica e interpretativa de uma inscrição neo-babilônica. Kerygma 1 (1): 39-44.

Tani, A. et al. 1997. ESR study of thermal history and dating of a stone tool. Appliance Magnetic Resonance 13 (3-4): 561-569.

Tite, M.S. 1972. Methods of physical examination in archaeology. Seminar, London.

Zink, A.; Porto, E. 2005. Luminescence dating of the Tanagra terracottas of the Louvre collections. Geochronometria 24: 21-26. 